\title{
MEDIATION OF THE POLYETHNOSPHERE AS A GLOBALIZATION PHENOMENON OF CULTURAL CONTINUUM
}

V.M. Sheiko. Mediation of the polyethnosphere as a globalization phenomenon of cultural continuum

The purpose of this research is to analyze a meaningful understanding of the definition of the polyethnosphere and to identify mediation trends in the relationship of the polyethnosphere with the processes of interexistence of various archetypes of the modern globalization world.

The methodologyy of this study is methods and principles of culturological analysis of mediation phenomena of the polyethnosphere as a phenomenon of globalization-civilization cultural continuum.

The results of this scientific research are connected with a detailed culturological analysis of the mediation of the polyethnosphere as a factor of the further civilizational evolution of the cultural continuum in the context of globalization.

The scientific topicality of the research is that by means of culturological methodological tools the issues of agency, mediation of the polyethnosphere as a phenomenon of evolution of the cultural continuum in the context of globalization are analyzed.

The practical significance of this article is that its results can be of interest in the preparation of methodological materials for history and theory of culture in higher education institutions, especially in the ones of the humanitarian specialization.

Keywords: culture, polyethnosphere mediation, global cultural continuum, nature, biosphere, ethnogenesis, sociogenesis, interexistence.

B. М. Шейко. Медіація поліетносфери як феномену глобалізаційного культурного континууму

Розглянуто поняття медіації поліетносфери як феномену глобального культурного континууму. Проаналізовано роль медіації як посередника поліетносфери в системі та умовах інтеріснування архетипів континууму сучасних культур. Визначено змістовні, етнічні та інші спектри формування поліетносфери як посередника, медіатора континууму культур у глобальному світовому просторі. Означено, що механізми медіації розвитку глобального континууму культур водночас сприяють формуванню поліетносфери як особливої оболонки ноосфери земної поверхні, що включає різноманітний органічний і неорганічний, рослинний і тваринний світи тощо.

Ключові слова: культура, медіація поліетносфери, глобальний культурний континуум, природа, біосфера, етногенез, соиіогенез, пасіонарність, архетипи, інтеріснування.

The analysis of the considerable amount of the published literature proves that most studies in this problem have only been carried out in its separate aspects. F. Baade in his monograph talks about the prospects for the future development of mankind, including world culture (Baade, 1962). Numerous studies have attempted to explain the ways of development of mankind and culture (H. S. Batishchev, V. S. Bibler, monographs of Y. P. Bohutskyi, I. M. Diakonov, article by H. S. Kysilov) (Batishchev, 1997; Bibler, 1998; Bogutsky, 2008; Dyakonov, 1994; Kiselev, 1999). Some scientific papers have revealed the modern problems of civilization and culture (articles by H. M. Kuzitsyn, I. Y. Leviash, fundamental monographs by J. Nesbitt, Y. M. Pakhomov, S. B. Krymskyi, Y. V. Pavlenko, V. V. Liakh, O. M. Sobol, Y. V. Liubyvyi, Y. V. Yakovets, N. N. Mokliak and others are about (Kuzitsyn, 1993; Levyash, 1999; Nesbitt, 1992; Pakhomov, 1998; Lyakh, Sobol, Lyubivy and others, 1995; Moklyak and others, 1993; Society on the threshold of the XXI century, 1999; Yakovets, 1992). The articles of M. A. Cheshkhov, V. M. Sheik, E. P. Yatsenko describe globalization and formation of culturology and national culture (Cheshkov, 1998; Yatsenko, 1999). Similar issues are analyzed in a number of foreign publications (Eder, 1996; Gore, 1992; Laszlo, 1996; Laszlo,

* This work is licensed under a Creative Commons Attribution-NonCommercial-ShareAlike 4.0 International License. 
1997). So far, however, only several studies have paid attention to the problems (Gumilev, 1992; Gumilev, 1993; Sheiko, Bogutsky, 2005; Sheiko, 1999; Sheiko, 2000).

Nowadays there is a small volume of published studies describing this topic. In recent years, there has been an increasing amount of literature on mediation such as a number of scientific and educational-scientific works. The generalizability of much published research on this issue is problematic. Thus, the textbooks by B. A. Leko, G. Chuiko investigate the essence and features of mediation (Leko, 2014; Leko, 2011). O. Kirdan, T. O. Podkovenko in the articles and theses suggest interpretations of the definition of "mediation" and historical aspects of its formation (Kirdan, 2019; Podkovenko, 2016). There is an interesting and fundamental monograph by N. A. Mazaraki highlighting the problems of the theory and practice of mediation in Ukraine (Mazaraki, 2018). The article by T. Kysilova on the history and development of mediation in the world is also of a great scientific interest (Kiselova, 2010).

One major theoretical point that is presented in the recent works concerns the role of mediation in resolving various conflicts (Alternative approaches to conflict resolution, 2007; Antonyuk,2014; Horowitz, 2004; Danilova, 2017; Kiselyova, 2019; Conflictology and mediation, 2018; Lyakh, 2015; Ryabinin, 2013; Yurkiv, 2018). In the major studies by E. M. Makarenko draws our attention to the management of ethnic conflicts (Makarenko), and T. Podkovenko defines mediation as one of the alternative means of resolving disputes and their impact on legal culture (Podkovenko, 2019). The main problem of the monograph by I. V. Danyliuk is ethnic psychology as a field of scientific knowledge (Danilyuk, 2010). And, finally, the findings by L. V. Matvienko and H. O. Panchenko on polyethnicity point out key factors in the process of nation-building in modern Ukraine (Matvienko, 2019). The books by $\mathrm{O}$. Maiboroda reported the cases of promotion of tolerance spreading in the field of polyethnic society (Mayboroda and others, 2002), and T. H. Stefanenko performed a similar investigation in the area of ethnopsychology (Stefanenko, 1999).

However, all the previously mentioned methods suffer from area limitations. Thus, the analysis of the available literature shows that today the topic related to the mediation of the polyethnosphere as a phenomenon of the globalization cultural continuum is still awaiting for its study and is of topical scientific interest.

Presentation of main material. This article aims to analyze the semantic understanding of the concept of the polyethnosphere as a special, particular and unique shell of the earth, the earth's surface, which, by the way, includes multicolor and diverse worlds of flora and fauna. At the same time we are talking about geological, geographical, biological, biospheric, ethnic and other aspects of the formation of polyethnosphere. And most importantly, it is planned to identify and analyze mediation trends and phenomena of the relationship between the polyethnosphere and the processes of interexistence in various archetypes of the general palette of cultures of the modern globalization and civilization world. At the same time, mediation acts as an agent that helps the phenomena of the polyethnosphere to interact with the continuum of cultures in the context of globalization.

The formation of the polyethnosphere is a multifaceted, extremely complex and selforganizingprocess ofearthcivilization(Bogutsky, 2008). Its functioning is the fundamental basis for the interexistence of colorful archetypes of the diverse palette of numerous cultures of the modern world community. In its turn, the interexistence in mediation of the continuum of modern cultures is the basis for cooperation of dialogue and polylogue of cultures of many peoples of the world, dialogue - as a guarantee of peace and harmony on Earth (Bibler, 1998; Kiselev, 1999; Levyash, 1999; Pakhomov, 1998; Society on the threshold of the XXI century, 1999; Sheiko, 1999; Sheiko, 2000; Yurkiv, 2018).

The basic measurement unit of history is ethnos (Sheiko, Bogutsky, 2005). It can be small and large, like Chinese, Russians, Bengalis, Arabs. An element of the ethnos structure is the subethnos, which may initially ensure the formation of the ethnos. Separate ethnic groups do not live in isolation from each other, they form something like an ethnic galaxy. According to Gumilev's claims, we have already found out that ethnos is not a fictional category or a philosophical generalization of certain features of people. Ethnos is given to us directly in feelings, as light, warmth, electric discharge, and we will study the polyethnosphere as one of the phenomena of nature, biosphere, and 
not as a humanitarian concept. Ethnic groups do not exist in isolation, with the exception of relict tribes, but even there the problem of outof-ethnic existence of individuals does not arise. They simply cannot be there, because the exile, deprived of the ethnic group - the homeland, the support of the collective, is doomed to death in harsh conditions.

However, ethnic groups directly studied by ethnographers are only the "tails" of long phases of development, the cause of which is, as already noted above, an explosion of passionarity, the result of uneven distribution of living energy of the biosphere on earth. An "explosion" on the surface of the globe is like a mutation that causes the development of free energy that is capable to do work, and this energy of the biosphere impulse is manifested in ethnic groups and living nature in the direction opposite to the principle of entropy. In other words, the process of ethnogenesis compensates for the attenuation of the energy charge or impact of the biosphere reserve on Earth and in space, turning the inertia of the recession into its opposition, into human life and struggle.

Then there is an expansion of the action area of the active ethnic group, the beginning of the age count-down of the ethnos - formation, crystallization, simplification of the structure, because of 600 yearsafteritsappearanceitbecomes too complex, stabilization of sociogenesis, then one or two centuries of "blood intakes" exaggerations, shock and then transfer to the inertial phase and establishment of harmonic equilibrium, homeostasis, "expectation" of a new volution of biosphere vibration. At the end of the way, the ethnos turns into an isolate, an ethnic collective with a miserable level of existence, over which journalists and politicians usually shed tears, because they do not know that these people have gone through everything, they are "grandfathers" and not "children" They are the source of civilization wisdom. Otherwise the isolate will turn into something socially unattractive - homeless, outcasts.

Prominent scientists, attentive to the facts of history, thanks to their methods calculated the duration of the initial rise of the ethnos, namely, the historical period of formation of "fresh" people and their political system - 300 years long. In addition, there is an alternation of ups and downs - also 300 years long, and then begins the weakening of life activity, which leads to the ordering of their destiny and prosperity of life, that was called by A. Toynbee a breakdown (breakdown, as biologists say). Finally, there is a final decay of will and a slow slide "to the abyss of life". All peoples have such fate.

According to L. M. Gumilev, new ethnic groups do not appear in monotonous landscapes - for example, heath, a space even to the horizon, dry plain did not promote the genesis of any people, as well as the taiga zone. Ethnic groups emerge on the border of landscape regions, in the zone of ethnic contacts, where intensive crossbreeding is inevitable. However, it is not a cause of ethnogenesis, but it adds anthropological material to the very form of contact and the evolution of the ethnos. It promotes the starting point of ethnogenesis of the combination of different cultural levels, types of state, dissimilar traditions. Common to history is the principle of diversity, which becomes a synchronous reproduction of the mosaic of the earth, its polyethnosphere.

L. M. Gumilev suggests to consider the ethnosphere (polyethnosphere) - a special shell of the geosphere, the Earth's surface includeing flora and fauna, geological and other processes, climate, waters and others that accompany lifetime - as a studied phenomenon of planetary scale according to Vernadsky. Thus, we come to the conclusion that the polyethnosphere and its mediation should be considered as one of the Earth's shells, but taking into account a large number of differences in the interaction of ethnic groups with the natural environment (Sheiko, 1999). Interethnic and historical collisions occur due to the participation of natural, including mutational, background. So, the mediation of the polyethnosphere can be understood as a series of processes of emergence of ethnic groups in certain regions: ethnogenesis, expansion of primary substrates, their transformation into a part of ethnic history of mankind and dissociation of ethnic groups, i.e. disintegration of ethnic groups. This is not related to the death of individuals of the disappearing ethnic group, but it is a recombination, shuffling of human populations - their incorporation into a new ethnic group (Sheiko, 1999). For example, the Spanish colonists in America were included into new ethnic groups, or the process of disintegration known in physics begins after an inertial shock. 
The decaying of ethnic groups in the polyethnosphere is very slow, because the energy reserves, as well as the material and social base of development created by human labor, political structures, management experience, and other attributes of the public organization of ethnogenesis stands against the tendency for decay.

L. M. Gumilev developed the problem of variants of ethnic contacts in the territories inhabited by different ethnic groups. He differentiates four variants: coexistence, assimilation, mestization and merging - when during the contact the traditions of both primary components are being forgotten and along with the two previous or neighboring ones, or instead of them a third one, a new ethnic group emerges. This is, in fact, the main variant of ethnogenesis. Anyway, this is how, for example, the Great Russian ethnic group or the United States emerged. But, of course, such a variant of ethnogenesis is not often observed in history.

According to the level of participation of ethnic groups in contact formations, Gumilev distinguishes several possible variants. One of them is the "xenia" variant, when two different ethnic groups get into the same social organism, for example, the Flemings and the Walloons in Belgium. And the variant of "chimera", when one ethnos at the stage of decay, breakdown of another ethnos appropriates the niche of the weakened ethnos and begins to function in it within the limits of dissonance, i.e. destruction of the environment native for the broken ethnos. Basing on the material of the Old and New World, Gumilev examined the second level variants, painful both for ethnogenesis and for scientists who study the problems of contacts and always take the side of one of the ethnic groups. (Gumilev, 1992; Gumilev, 1993).

Thus, we have the necessary tools for further study of peoples in the polyethnospheric shell of the globe.

Thus, the mediation functioning of the polyethnosphere becomes the foundation of interexistence of various archetypes of the entire palette of modern cultures of the world. On the other hand, the mediation of the polyethnosphere in the context of globalization promotes the evolution of the world cultures continuum.

As it is widely known, culture is a powerful factor of human activity: it is present in everything we see and feel, and everything we see and perceive comes to us with colored expectations and inclinations. They are based on our culture: we see the world through the prism of the color of our culture. A huge number of people use this prism without even suspecting its existence. People's actions directly depend on what they believe in, and their beliefs, in their turn, depend on the culturally determined vision of themselves and the world around them.

Despite the fact that the existing living cultures are under strong pressure in order to neutralize and unify them, they differ in values, views and ideas about a human and the space. The diversity of cultures deserves to be known more closely, because it makes up the attitudes and behavior of the people of each culture. Moreover, by influencing all other cultures, each culture also forms relations throughout the entire multicultural world (Sheiko, 2000).

In the process of historical development, great cultures of mankind arose and created their vision of the world. At the dawn of history, the world seemed animistic: not only people had souls, but also animals and plants - everything in nature was alive. The spring in the savannah evoked pious fear of the spirits and forces of nature, as well as of the souls of the dead; a deer, which accidentally got into a human settlement, was identified with the spirit of an ancestor who visited his relatives; thunder was considered as a sign of the Great Mother or the almighty Father. Throughout the whole written history, traditional cultures have been overwhelmed by stories of the sensory perception of invisible beings in a symbolic hierarchy.

The classical culture of ancient Greece replaced the myth-based view of the world with concepts based on thinking, although the latter was seldom verified by experiments and observations. Since biblical times in the West and for several millennia in the East, the views and images of religion (or other accepted belief systems) have dominated people's views. This influence significantly weakened in the XVI and XVI centuries, when experimental science emerged in Europe. Over the last three centuries, scientific and technological culture has begun to dominate over the mythological and religious views of the Middle Ages, although it has not completely supplanted them.

In the XX century the scientific and technological culture of the West spread throughout the globe. Non-Western cultures 
are now solving a dilemma: to open the door to Western culture or to close and continue the traditional way of existence, preserving the usual way of life, activities and cults.

The Western culture is individualistic and person-centric. It considers personal values, freedom and the aspiration to happiness as sacred things. Nature and all beings exist mainly for the good of a human. In addition, the Western culture is pragmatic: it overrides much of what cannot be seen or grasped - that is, what cannot be "presented" to a hand or an eye (Laszlo, 1996). The exception is the JudeoChristian belief system with its transcendent God, a host of saints and other otherworldly beings, and faith in the immortal soul. As for spirits, as well as other intangible and invisible beings to which traditional cultures reverently bow, the proponent of Western culture with a scientific cast of mind simply dismisses them as superstitions, although many people often adhere to opposite views.

In recent years, despite "Coca-Colonization" and "McDonaldism", the values and notions of the Western culture have come into resistance. A new kind of cultural nationalism has emerged in South America. Latin Americans are outraged by their dependence on North America; they express dissatisfaction with their role as consumers, but not the creators of the cultural movements that make up the modern world. The dominance of foreign culture is experiencing agony in the minds of educated Arabs; they perceive the Western tradition as an element of Western hegemony over their countries. Arabs perceive themselves as passive participants of an intercultural dialogue, which connects them almost exclusively with Western Europe and North America (Laszlo, 1996).

India and the countries of Southern Asia, although continuing mediation contacts with British culture, assimilating many of its distinctive features, began to actively defend their own cultural heritage. Russia has accumulated extensive historical experience of an ambivalent attitude to Western culture; this attitude is still maintained. Its main features are the recognition of the Western achievements in both technology and high culture, but at the same time the fear that these achievements may stifle Russian cultural heritage and thus deprive the Russian people of their identity.
Admiration for Western culture, along with fear of it, is also characteristic for the young African nations of the Sahara. But greedily consuming industrial culture, they also make great efforts to protect their cultural heritage. African intellectuals are busy searching for the roots of their racial identity, and their leaders are eager to strengthen the national identity of their peoples.

Contrasts to Western approaches of worldview and oneself are quite real, although they are not always realized. For example, Latin Americans have a more highly developed spirituality than the populations of the United States and Canada have. This has its historical roots: the transcendentalist elements of Latin American culture date back to the XV century. For the whole South America, the Catholic scholasticism of the European Middle Ages was something more than just monastic philosophy: scholasticism played the role of a cognitive system internally peculiar to the state and its society, and controlled all aspects of life. Latin Americans have been taught that happiness is sent down as the grace of God, which in its turn is the exclusive prerogative of the Catholic Church. Not surprisingly, submission to the authority of the church, as well as fidelity to the king and obedience to God, became an axiom in everyday morality. Even when the colonial era was over, the accommodation between scholastic heritage and modern scientific thought did not take place. Anglo-Saxon pragmatism, based on the application of concepts and methods of the natural sciences to the material sphere of life, hasn't succeeded in establishing in Latin America.

Transcendentalism, although in various forms, is a hallmark of Hindu and Buddhist cultures on the Indian subcontinent; in Muslim culture, monotheism and mysticism are mixed with this. The indigenous cultures of Black Africa have always been characterized by spiritualism and animism; these elements were not "eroded" by the fanaticism of Christian missionaries nor by the marketing propaganda of transnational corporations.

Eastern thinking retains many features of its traditional beliefs. A wide range of cultures that emerged from China over the last millennium were formed under the influence of Lao Tzu's naturalism, Confucius' social discipline, and the Buddha's relentless concerns for personal 
improvement. In the XX century these cultural sources were divided into numerous movements, giving rise to the orthodox culture of the Maoist Yan'an, the pragmatic culture of the Hong Kong Kong-Dao, and also to the mixture of naturalism, Confucianism and Buddhism characteristic to modern Japan. Since the Kong-Dao and Japanese branches of the Chinese cultural tradition have retained a commitment to everything concrete and practical, it is not surprising that societies in which these traditions have become widespread do not experience any difficulties in adopting or even improving them. The cultures that we named "modernized" but did not succumb to Westernization. Their own kind of modernism retains its cultural specificity - it is for this reason that similar work skills and group passions cannot be easily and simply transplanted to Europe and America.

What is the manner of coexisting in mediation of all these so different cultures on our small planet, where everything is interdependent, remains a great mystery. It is clear that each culture needs to develop independently, respecting its roots and traditions, but at the same time evolving to the values and views that allow its supporters to live in harmony with other cultures and nature. This is a basic requirement. The clash between cultures is far more dangerous for the world in the global community than the armed conflict between any nations-states.

If there are no positive changes, the mediating communities belonging to the Western cultural sphere will find themselves on the verge of a catastrophe that is brewing in relations between Islamic, Orthodox Christian, Chinese, Latin and other cultures, where different from Western Christian values and views are adhered to. The Balkan "hot spot" can serve as a convincing example that confirms the realism of such a scenario. When in the XV century the Ottoman Empire invaded Bosnia, then in addition to the two cultures that existed in the Balkans after the partition of the Roman Empire under Constantine - Roman Catholic and Greek Orthodox - a third one was added, i.e. Islam. Since then, skirmishes have taken place between these three cultures from time to time. Following the break-up of Yugoslavia, once united by Tito under the banner of communism, the mutual intolerance of these three cultures led to bloody massacres in the 1990s.
But the scenario "West and the rest of the world" is not only a potential possibility. People of different world cultures have many common interests in relation to the environment and other issues. It is vital for them that differences in cultural values and goals do not obscure those areas where their interests coincide.

For the positive mediation development of world cultures, more efficient and responsible use of the currently formed information and communication systems is important. The latter can connect people within a given culture, as well as people who belong to different cultures. Closer relations will reduce hostility, reduce the potential for conflict and strengthen mutual understanding. Mutual relations will help people of different cultures to identify common interests and pave the way for mutual harmonization of their goals.

However, there are obstacles for the free flow of information within the entire globe that are not so easy to overcome. Journalists who publish reports and articles on topics that are undesirable for local authorities face threats, obstacles in their work, arrests, assaults, kidnappings and even murders. The press and communication means are banned or destroyed. The International Freedom of Expression Exchange (IFEX) network receives more than 1500 complaints a year from journalists and issues more than 1000 alarming messages; it also receives about 500 complaints of violence against press centers, including the seizure of apartments, arsons and bombings, the temporary suspension of publishing houses work, bans, censorship, financial pressure and law enforcement bodies arbitrariness (Laszlo, 1997). It should be kept in mind that these complaints are just the peak of the iceberg, and journalists do not report about far larger part of the harassment because of fear of repressions by local government.

The press, which is constantly kept at gunpoint by the local authorities, cannot be the property of the people. In all developing countries, ordinary people, especially women, do not have access to the mass media. African and Latin American women work in the fields, babysit at home, and no one is interested in their opinion. Under such circumstances, the enormous potential of modern global communication networks remains tragically unused.

Ordinary people's access to mediation means of mass media and freedom of speech, which allows 
journalists to report on the fates, concerns, hopes and anxieties of ordinary workers, are crucial for better understanding between peoples and cultures. It is possible to identify and effectively embrace unity in the diversity of cultures only if the peoples know each other, create what unites them, identify ways of cooperation to achieve common goals. Peoples and cultures need to go beyond the stage of tolerance alone, if such one exists, and rise to the stage of an active and charitable mutual cooperation. In order for such a transition would take place, there must exist an understanding generated by contacts and achieved through communication.

Such mediative collaboration could raise the modern world from the level of existence to a new, higher level of coexistence, which is characterized by participatory relations. In its turn, this could pave the way for global interexistence (Baade, 1962; Batishchev, 1997; Bibler, 1998; Dyakonov, 1994; Kiselev, 1999; Levyash, 1999; Nesbitt, Eburdin, 1992; Pakhomov, 1998; Lyakh, Sobol, Lyubivy, and others, 1995; Moklyak and others,1993; Society on the threshold of the XXI century, 1999; Cheshkov, 1998; Sheiko, 2000; Yatsenko, 1999; Eder, 1996; Gore, 1992) and the formation of a new polyethnosphere (Sheiko, 1999).

Mediation interexistence implies a relationship of active participation instead of passive, purely tolerant relations. Interexistence encourages not just to live side by side, but to actively cooperate. There has always been an interexistence inside social groups; even in traditional societies, life is interdependent and based on the achievement of common goals. However, relations between different groups were rarely based on the recognition of common interests. At the time of the emergence of cultures, other tribes were insignificant for the existence of the group, and that's why the group was in most cases indifferent to other communities or, if they posed a threat, was hostile to strangers. And only with the emergence of agriculture and livestock, when people moved to a sedentary lifestyle, the neighboring tribes began to unite, creating cities and villages. Later, these settlements were integrated into broader social and political systems. Some of these systems (such as Ancient Babylon and Egypt, as well as the classical empires of India, Persia and China) have existed for millennia.
Later, city-states, kingdoms and principalities began to practice some forms of interexistence within entire regions or continents. But the interexistence never covered the whole globe. Even Pax Romana, that united the peoples of all the continents known at that time, was based mainly on the power of Rome but not on the common interests of many peoples.

In the modern world, regional, economic, social and political integration act as a driving force that pushes sovereign nation-states to broader forms of interexistence. Europe is the example. In such different areas as economics, finance, environmental protection, technology development and national defense, the member states of the European Union are steadily, though not without hesitations, advancing to the era of interexistence.

At the turn of the new millennium, it is time to give a new, global dimension to the regional interexistence that we have today. interexistence has spread over the entire planet: each nationstate and each regional community has felt dependency on other states and communities in terms of its economic and ecological wellbeing and territorial security as well. There is a complete harmony of interests in all these spheres. Thus, the relations between separate nations, as well as between groups integrated in regional scale, should be full of the logic of mutual participation, and not by the logic of passive and indifferent tolerance.

The logic of interexistence is you and me, they and we. It replaces the logic of selfishness and exclusivity, which recognizes only "I or you", "we or they". The logic of participation is primarily "engaging" by its nature; a zero-sum game ("I'll win, you'll lose") between rivals is replaced by a game with a positive sum ("I'll win, you'll win") of partners. As long as each of the players sees his interest in the defeat of the other, the victory of one will mean the loss of the other (the sum of the winnings of one and the losses of the other will be equal to zero). But when players feel like partners with higher goals, they will realize that their interests coincide, they will start playing a game in which the sum of wins and losses is positive: the one's win means the win of the other.

Games with positive sum even exist in such traditionally conservative areas as banking. Micro loans, sometimes as little as $5 \$$, have already helped 8 million families around the world. It 
is expected that up to 100 million families will be able to use the loans by 2005 . The pioneers of micro loans creation were organizations such as Grameen Bank in Bangladesh and the Women Association, which started their own business in India. Since 1996 Grameen Bank has been issuing one-year loans of $120 \$$ to start own business: to buy a cow or a sewing machine. To date, $99 \%$ of issued loans have been repaid due to a simple but effective algorithm. A group of similar borrowers is created, which studies the loan repayment plan and assumes responsibility for their effective use. The group chooses its members, studies and approves their projects and can even help to repay the loan. Such a group in practice implements a game with a positive sum - interexistence (Laszlo, 1997).

Most games with a positive amount are found in the international sphere. The main ones are peace and security, family planning, economic development and a healthy environment. To play such games means to destroy nuclear, biological, chemical weapons, as well as the most deadly conventional weapons and create a common system for maintaining peace on the globe, to reduce the birth rate in the regions where it is excessive, to use handicrafts, technologies and capital together with poorer or less developed partners, to invest in areas such as education, communications and human resources development, as well as in the construction of economic and social infrastructure, to adhere to balances and thresholds vital to the integrity of nature.

With the inherent active participation logic to interexistence, it creates a basis for the use of mutually enriching additional aspects in the diversity of cultural perceptions. Different cultures can work together on a mutually beneficial basis, supporting and developing the multicultural world of which each culture is a part.

It is in our common interests to work for the benefit of the system of which we are all a part. This is reflected in the term "interexistence". "Inter" in Latin means "between", "among", and "esse" means "to exist", "to be". Putting the Latin words together, we get "interesse" - the root of the modern word "interest". This allows us to turn again to the sources and make sure that the logic of interexistence determines our deepest and the most important interests in a culturally diversified, but socially, economically and ecologically interdependent world.

Nowadays, intolerance is suicidal, but tolerance alone is not enough. The transition from the coexistence of great states to mediation cultural interexistence is one of the most urgent requirements of the modern globalizational and civilizational world.

Conclusions. Thus, the analysis of the processes of mediation formation of the polyethnosphere shows that these planetary phenomena ensure the existence of life itself on Earth. Due to these processes, an environment for collaboration, co-existence of different ethnic groups, different peoples and their cultures, is created. In addition, the mediation formation of the multicultural world requires from humanity respect to the Nature, taking into account the need for collaboration with it. The latter becomes a guarantee of the possibility of further coexistence of the peoples of the world as well as the Earth civilization as a whole in the age of globalism.

\section{References}

Alternative approaches to conflict resolution: theory and practice: a guide (2007). N. M. Haiduk and others. (Cjmp.). Lviv: PAIS. [In Ukrainian].

Antoniuk, O. A. (2014). Mediation and good services in the system of international conflict resolution. Normatyvni, upravlinski ta mizhnarodni aspekty rozvytku ekonomiky ta prava, Proceedings of the I scientific-practical conference, September 2, 2014, Odesa. Public organization "All-Ukrainian Center for Economic Law”. (Pp. 44-50). Odesa. [In Ukrainian].

Baade, F. (1962). Competition for 2000. Our future: heaven on earth or self-destruction of mankind. Moscow: Inostrannaja literatura. [In Russian].

Batishchev, G. S. (1997). Culture outside of life and life outside of culture. Kul'tura i sud'by mira. Universalizm regional'nogo (pp. 153-156). Moscow. [In Russian].

Bibler, B. C. (1998). Civilization and culture: philosophical reflections on the eve of the XXI century. Vestnik Rossijskogo gosudarstvennogo gumanitarnogo univresitetata: a collection of articles. (Issue 2, pp. 9-49). Moscow. [In Russian].

Bohutskyi, Yu. P. (2008). Self-organization of culture: ontology, dynamics, perspectives: monograph. Kyiv: Veselka. [In Ukrainian].

Horowitz, D. L. (2004). Interethnic conflicts: with a new preface. Kharkiv: Caravela. [In Ukrainian].

Gumilev, L. N. (1992). Rhythms of Eurasia. Our contemporary, 10, 25-31. [In Russian]. 
Gumilev, L. N. (1993). Ethnosphere: History of People and History of Nature. Moscow: Ekopros. [In Russian].

Danylova, T. V. (2017). Mediation of intercultural conflicts: a few words about the parable. Naukovyi visnyk NUBIP Ukrainy. Seriia: Humanitarni studii, 274. 15-20. [In Ukrainian].

Danyliuk, I. V. (2010). Ethnic psychology as a branch of scientific knowledge: historical and theoretical dimension: monograph. Kyiv: Summit-Knyga. [In Ukrainian].

Diakonov, I. M. (1994). The paths of history: from the earliest man to the present day. Moscow: Vostochnaja literatura. [In Russian].

13.Kiselev G. S. (1999). "The crisis of our time" as a human problem. Voprosy filosofii, 1, 40-52. [In Russian].

Kiselova, T. (2010). The history of the origin and development of mediation in the world. Retrieved from https://www.academia.edu/3371628/History of Mediation Movement 2010 How Everything began_the_story_of_the_origin_and_development of media [In Russian].

Kiselyova, T. (2019). Concepts and main trends of dialogue as a mechanism for conflict resolution and decision-making in Ukraine. 5 rokiv dialohu $i$ 25 rokiv mediatsii v Ukraini: vid protystoiannia do porozuminnia: a collection of articles (pp. 236243). Kyiv. [In Ukrainian].

Kirdan, O. (2019). The concept of "mediation" and approaches to its interpretation in modern scientific discourse. Pedahohichnyi chasopys Volyni, 2, 1220. [In Ukrainian].

Conflictology and mediation: a textbook (2018). Chernivtsi: Chernivtsi National University. [In Ukrainian].

Kuzitsyn, G. M. (1993). Cultural progress of mankind: problems, search, solutions. Kul'tura, iskusstvo, chelovek, Collection of scientific articles, theses and reports of the scientific-practical conference (March 25-26, 1993). Perm State Institute of Arts and Culture (pp. 5-15). Permian. [In Russian].

Leviash, I. Ya. (1999). Civilization and culture: logos, topos, chronos. Chelovek, 5, 43-55. [In Russian].

Leko, B. (2014). Mediation: a textbook. Chernivtsi: Knygy - XXI. [In Ukrainian].

Leko, B. A. (2011). Mediation: a textbook. Chernivtsi: Knygy - XXI. [In Ukrainian].

Liakh, T. L. (2015). Mediation as a social technology of mediation in conflict situations. Visnyk Luhanskoho natsionalnoho universytetu imeni Tarasa Shevchenka. Pedahohichni nauky, 2 (1), 52-60. [In Ukrainian].

Mazaraki, N. A. (2018). Mediation in Ukraine: theory and practice: monograph. Kyiv: Kyiv National University of Trade and Economics. [In Ukrainian].

Makarenko, E. M. Features of ethnic conflict management. Retrieved from http://www.academy. gov.ua/ej/ej13/txts/Makarenko.pdf. [In Ukrainian]
Matvienko, L. V. (2019). The phenomenon of polyethnicity as a key factor in the process of nationbuilding in modern Ukraine. Hileia: scientific bulletin: collection. (Issue 140 (№ 1), part 3: Political Science. Pp. 43-47). Kyiv. [In Ukrainian].

Nesbitt, J., Eburdin, G. (1992). What awaits us in the 90s. Megatrends. Year 2000. Moscow: Respublika. [In Russian].

Pakhomov, Yu. N. (1998). Paths and crossroads of modern civilization. Kiev. [In Russian].

Podkovenko, T. O. (2016). Mediation: historical aspects of formation. "Ukraina $v$ umovakh reformuvannia pravovoi systemy: suchasni realii ta mizhnarodnyi dosvid", Proceedings of the International scientificpractical conference: abstracts of scientific reports (April 8-9, 2016). Ternopil National University of Economics, Faculty of Law. (Pp. 207-210). Ternopil. [In Ukrainian].

Podkovenko, T. (2019). Mediation as one of the alternative ways of resolving disputes and its impact on the legal culture of society. Aktualni problemy pravoznavstva, 1, 11-16. [In Ukrainian].

Liakh, V. V., Sobol, O. M., Lyubivy, Ya. V. and others (1995). Rekonstruktsiia svitohliadnykh paradyhm (novi tendentsii $v$ zakhidnii filosofii). V. V. Lyakh (Editor-in-Chief). Kyiv: Naukova Dunka. [In Ukrainian].

Riabinin, E. V. (2013). Causes and methods of resolving interethnic conflicts: a theoretical aspect. Visnyk Kharkivskoho natsionalnoho universytetu im. V. N. Karazina. Seriia: Pytannia politolohii. (Issue 24, № 1073. pp. 173-178). Kharkiv. [In Ukrainian].

Mokliak, N. N. and others. (1993). Social relations: problems, development prospects: monograph. Kiev: Naukova Dumka. [In Russian].

Maiboroda, O. and others (2002). Promoting tolerance in a polyethnic society: a guide. Kyiv: Fond «Ievropa XXI». [In Ukrainian].

Stefanenko, T. G. (1999). Ethnopsychology: a textbook for university students with a degree in Psychology. Moscow: Akademicheskij proekt. [In Russian].

Society on the threshold of the XXI century: a philosophical understanding of the fluid world (1999). Kyiv. [In Ukrainian].

Cheshkov, M. A. (1998). Globalistics: subject, problems and prospects. Obshhestvennye nauki $i$ sovremennost', 2, 129-139. [In Russian].

Sheiko, V. M., Bohutskyi, Yu. P. (2005). Formation of the foundations of culturology in the era of civilizational globalization (second half of the XIX - beginning of the XXI century): monograph. Kyiv: Genesis. [In Ukrainian].

Sheiko, V. M. (1999). Interest of cultures and the concept of polyethnosphere (to the problem of correlation of concepts). In Skhid-Zakhid: historical and cultural collection (Issue 2. P. 160-173). Kharkiv. [In Ukrainian].

Sheiko, V. M. (2000). Continuum of cultures: problems of interdependence and cooperation. Kultura 
Ukrainy: a collection of scientific works (Issue 6: Art History. P. 4-12). Kharkiv. [In Ukrainian].

Yurkiv, Ya. I. (2018). Mediation as a way to resolve conflicts. Visnyk Luhanskoho natsionalnoho universytetu imeni Tarasa Shevchenka. Pedahohichni nauky, 8(2), 264-271. [In Ukrainian]. Yakovets, Yu. V. (1992). Anticipating the future: the paradigm of cyclicity. Moscow. [In Russian].

Yatsenko, E. P. (1999). Modernization and national culture. In Kul'tura $v$ sovremennom mire: opyt, problemy, reshenija: scientific and information collection. (Issue 4. P. 3-20). Moscow. [In Russian].

Eder, K. (1996). The social construction of nature: A sociology of ecological enlightment. Thousand Oaks (Cal.): Sage publ. [In English].
Gore, A. (1992). Earth in the balance: Ecology and the human spirit. New York: Houghton Mifflin Co. [In English].

Laszlo, E. (1996). Evolution: the General Theory. Cresskill, N.Y.: Hampton Press. [In English].

Laszlo, E. (1997). The Choice: Evolution or Extinction. Cresskill, NewYork: Hampton Press. [In English].

Надійшла до редколегії 30.11.2020 